\title{
Clinical and Pathological Assessment of Aloe Vera and Propolis for Wound Healing in
} Normal and Diabetic Albino Rats

\author{
Abdel-Nasser A.A. Abdel-Hady ${ }^{1}$, Mouchira M. Mohi-Eldin ${ }^{2 *}$ and Ahlam A.A. Allaam ${ }^{2}$ \\ ${ }^{1}$ Surgery, Radiology and Anesthesiology Department, Faculty of Veterinary Medicine, South \\ Valley University, Qena, Egypt \\ ${ }^{2}$ Pathology and Clinical Pathology Department, Faculty of Veterinary Medicine, South Valley \\ University, Qena, Egypt
}

Article History: Received: 17/7/2017 Received in revised form: 27/10/2017 Accepted: 1/11/2017

\begin{abstract}
The study was conducted to evaluate the role of topical application of either aloe vera gel extract or propolis ointment on wound healing in diabetic and non-diabetic animals. Ninety adult female albino rats weighing (180 $\pm 200 \mathrm{gm})$ were divided into 2 groups (A; non-diabetic) and (B; diabetic), each group was further subdivided into 3 subgroups. Group A contains subgroups 1, 2 and 3 but group B contains subgroups 4,5 and 6 . Subgroups $(1,4)$ were experimentally punched for induction of skin wound and left untreated for 2 weeks. The wound in both subgroups $(2,5)$ were treated with Aloe vera extract topically daily. Subgroups $(3,6)$ skin wound was treated with $10 \%$ propolis ointment topically twice daily for 2 weeks. The rats were examined daily during the experiment for any abnormality or mortality rates. Blood samples were collected, besides skin wound specimen from all sacrificed rats on 3, 7, and 14 dpi for cellular immune response and histopathological examination, respectively. Both treated rats mainly (subgroup 2, 3 and 6) were responded to treatment with rapid healing which begin from 7 dpi compared to (subgroups $1,5)$ which showed delayed healing. However, subgroup (4) was difficult to response to recovery until $14 \mathrm{dpi}$. It could be concluded that both propolis and Aloe vera accelerated the healing process in both diabetic and non-diabetic wounded animals.
\end{abstract}

Keywords: Albino rats, Aloe vera, Alloxan Monohydrate, Wound, Propolis.

\section{Introduction}

Alloxan monohydrate is the most commonly chemical used for induction of diabetes mellitus in experiment of animals, resulting in generalized hyperglycemic status $[1,2]$. Diabetes mellitus is classified into two types, type-I [insulin-dependent diabetes (IDDM)] and type-II [non-insulin-dependent diabetes (NIDDM)] [3] which had a metabolic disorder characterized by insufficiency of insulin secretion [4]. The pathophysiological relationship between diabetes and impaired healing is complex, and associated also with neuropathy, microangiopathy and impaired immune function [5]. Macrophages are responsible for the production of proinflammatory cytokines as (IL-1 $\beta$, IL-6, IL12 , IL-18, and TNF- $\alpha$, besides IFN- $\gamma$ ) in vivo and in vitro. It has a role in promoting inflammation, angiogenesis, leukocyte and stem cells recruitment, which lead to epithelization in wound healing [6,7]. Whereas, depletion of macrophages during the inflammatory wound, induced delay of healing

wound in a mouse [8]. Nowadays, there is an increased attention to medicinal products as complementary and alternative medicine in humans and animals, which involving several plants used for treatment and prevention of infectious and non-infectious diseases. Aloe vera is a plant species of the genus Aloe which is a member of the lily family, it has a clear, gel-like sap in the inner layer, it can be used topically because it has wound healing properties [9]. Aloe vera has several active biological components, such as vitamins (A, $\mathrm{C}, \mathrm{B}$ and $\mathrm{E}$ ), magnesium, calcium, copper, zinc, manganese, $\beta$-carotene and phosphorous in addition to several enzymes [10]. The honey bee products were used as a medicinal since ancient times [11]. Beehives contain propolis, which can be extracted and known as rude propolis. It is composed from balsam resin, essential and aromatic oils, pollen and wax besides wood fragments [12]. It has antibacterial, antiviral and antifungal effects [13].

*Corresponding author email: (mouchira_path@ vet.svu.edu.eg), Pathology and Clinical Pathology 
Propolis is used topically for inflammation, irritation, burns, sunburn, insect bites, besides surgical incisions [14]. The role of propolis in repair is related to its polyphenols to downregulate the activation of NF-KB which regulates the immunity and inflammation, where it suppresses inflammatory mediators such as TNF- $\alpha$, NO-Lipopolysaccharides for the protection of eNOS expression which enhances the process of healing. Propolis is a protective inhibitor for lipid and protein oxidation leading to the production of ROS and RNS that increase inflammatory responses and tissues damage.

The aim of this study was to assess the immunologic role for topical application of either Aloe vera extract and propolis ointment on the wound healing in diabetic and nondiabetic albino rats by cytokines analysis as well as histopathological examination [15].

\section{Materials and Methods}

\section{Experimental animals}

One hundred adult female albino rats (average body weight $180 \pm 200 \mathrm{gm}$ ) at age 3-4 months were obtained from Abou Rawash Farm, Giza, Egypt. Rats were examined 2 weeks prior the experiment to ensure that they were free from parasitic, viral and bacterial infection. This study was approved by the Animal Ethics Committee at South Valley University, Qena, Egypt. All animals were acclimatized in cages, in a well-ventilated room, one week before the experiment. The animals were kept under standard conditions (23 $\pm 3^{\circ} \mathrm{C}$ temperature), $(60-70 \%$ relative humidity), (12 h light/dark cycle), and fed on standard commercial pellets, and water $a d$ libitum along the experiment.

\section{Chemicals}

Alloxan Monohydrate (2, 4, 5, 6pyrimidinetetrone) is oxygenated pyrimidine derivative with the chemical formula $\mathrm{C}_{4} \mathrm{H}_{2} \mathrm{~N}_{2} \mathrm{O}_{4}$. It is present as alloxan monohydrate in aqueous solution. It was obtained from Sigma Company for pharmaceutical drugs, USA.
Aloe vera was obtained from a farm belonging to the Faculty of Agriculture, South Valley University, Qena, Egypt. Aloe vera gel was prepared freshly by washing Aloe vera leaves with water and swap followed by alcohol. The inner mucilaginous parenchymatous tissues of the leaves were separated out by sterile knife, and homogenized in a blender (at $30 \mathrm{rpm}$ ). The gel was obtained by through excision of the external parts of the leaves, and then the gel was squeezed, gridded and filtered.

Propolis was obtained from special farm belonging to Faculty of Agriculture, South Valley University, Qena, Egypt. Propolis extraction and tincture were prepared by collection of propolis from the bee hive (clean and free of wax, paint, wood etc), the proper amount of alcohol and propolis were placed into a container and the top was sealed, shake and stored in a warm dark place inside a brown bag on the counter (two or three times per day). The container was then shaken and returned to warm dark place and the process was repeated for 2 weeks and the liquid was filtered through a coffee filter (recommended that concentrations should not be higher than $30 \%$ extracted). For propolis tincture concentration, setting the container with the cover off, until the correct amount was evaporated off, then nine parts vaseline were mixed with one part of their extract.

\section{The experiment}

One hundred adult female albino rats (average body weight $180 \pm 200 \mathrm{gm}$ ) at age 3-4 months were divided into two groups $\mathrm{A}$ and $\mathrm{B}$ (non-diabetic and diabetic group, $n=50$, each).

\section{Induction of diabetes}

The rats in group $A(n=50)$, were fasting for twelve hours before induction, then injected intra-venous with freshly prepared $2 \%$ alloxan monohydrate solution at the dose of 40 $\mathrm{mg} / \mathrm{kg} \mathrm{BW}$. Blood glucose level was estimated $48 \mathrm{~h}$ after alloxan injection, using Glucometer ${ }^{\circledR}$ apparatus. The rats of this group recorded glucose levels greater than 400-550 $\mathrm{mg} / \mathrm{dl}$, they were continuously examined for one week for morbidity and mortality before beginning of the experiment. 


\section{Wound creation}

According to Carvalho et al. [16], experimental wound was performed in both non-diabetic and diabetic groups. Each rat was shaved from the dorsal region and cleaned with $70 \%$ ethyl alcohol, under the effect of light anesthesia with diethyl ether, a circular area of the skin was removed (with $10 \mathrm{~mm}$ diameter punch) in the mid-region between the infra scapular line and the base of the tail. Wounds were uniform in diameter, depth and location without incision of the muscle layer and tension of skin kept constant during the procedure. The wound was washed with $10 \%$ povidone iodine. The morbidity and mortality of diabetic and wounded animals were isolated and the experiment was established with ninety animals, divided into two groups (A, B), each was divided into 3 subgroups $(1,2,3)$ and $(4,5,6)$ respectively.

\section{Experimental design}

Groups A, B (non-diabetic and diabetic animals) $(n=15)$ contained subgroups 1 and 4 : the punching wound left untreated (nondiabetic and diabetic control). Subgroups 2 and 5: the punching wound treated with Aloe vera extract topically daily. Subgroups 3 and 6: the punching wound treated with $10 \%$ propolis ointment topically twice daily. The treatment was continuous for 2 weeks, until the end of the experiment (approximately time of healing). The animals were examined daily, clinical signs and process of healing follow up and wound skin surface measurements were recorded. Time of healing process was the time elapsed from the time of wounding until complete skin healing.

The healing follow up and method of measurement

Healing time $=[$ date of healing $(\mathrm{DH})-$ date of wounding] [12].

Wound surface area $($ WSA $)=\pi r^{2}\left(\mathrm{~cm}^{2}\right)$

Wound contraction percent $(\mathrm{WCP})=100 \%$ $\mathrm{WSAP} \%=\%$

Wound surface area percent (WASP)

$$
=\frac{\text { wound surface area } 100}{07 \mathrm{R}} \%
$$

\section{Estimation of TNF-a \& IL-10 levels in plasma by ELISA}

The animals were euthanized with xylazine $(40 \mathrm{mg} / \mathrm{kg})$ and ketamine $(400 \mathrm{mg} / \mathrm{kg})$ [17]. Blood samples were collected and plasma from non-diabetic and diabetic groups at 3, 7 and 14 dpi was separated. Cytokines evaluation, mainly tumor necrosis factor (TNF- $\alpha$ ) and interleukin 10 (IL-10) cytokines were carried out by ELISA [18].

The quantitative evaluation of the TNF- $\alpha$ and IL-10 levels in the plasma were carried out using mouse ELISA kits that were purchased from Boster Biological Technology Co. (CA, USA). The test samples and cytokine standards were added to 96-well plates coated with coating antibody, and the plates were then incubated at $37^{\circ} \mathrm{C}$ for $90 \mathrm{~min}$. After incubation at $37^{\circ} \mathrm{C}$ for $30 \mathrm{~min}$, the plates were developed with tetramethyl benzidine at $37^{\circ} \mathrm{C}$ for $20-25$ min. The reaction was stopped by the addition of $100 \mu \mathrm{L}$ of stop solution. The absorbance was measured using an ELISA reader at 450 $\mathrm{nm}$. The concentrations of TNF- $\alpha$ and IL-10 were calculated according to the standard curve using each of the recombinant cytokines in the ELISA kits.

\section{Pathological Examination}

The rats were examined daily for any gross picture abnormalities in healing process of wounds. All animals were sacrificed on 3, 7 and 14 dpi. Specimens from skin wounds were collected from euthanized rats, then fixed in $10 \%$ neutral buffered formalin and embedded in paraffin wax. Five microns thickness sections were prepared and stained with Harries hematoxylin and eosin for histopathological examinations [19].

\section{Statistical analysis}

Statistical analysis was done using oneway analysis of variance (ANOVA) to compare between control and other treated groups, followed by post-hoc analysis (Dunnett's test) using SPSS (Statistical Package for Social Sciences) version 17 [20]. The data were presented in the form of Mean \pm Standard Deviation. The difference was considered statistically significant when $\mathrm{P}<$ 0.05 . 
Table 1: Mean \pm Standard Deviation of the wound surface area (WSA), wound surface area percent (WSAP), and wound contraction percent (WCP) among different groups at 3,7 and14 days post induction

\begin{tabular}{|c|c|c|c|c|c|c|c|c|c|c|c|}
\hline Groups & Subgroups & $\begin{array}{c}\text { WSA } \\
\text { (3 days) }\end{array}$ & $\begin{array}{c}\text { WSAP } \\
\text { (3 days) }\end{array}$ & $\begin{array}{c}\text { WCP } \\
\text { (3 days) }\end{array}$ & $\begin{array}{c}\text { WSA } \\
\text { (7 days) }\end{array}$ & $\begin{array}{c}\text { WSAP } \\
\text { (7 days) }\end{array}$ & $\begin{array}{c}\text { WCP } \\
\text { (7 days) }\end{array}$ & $\begin{array}{c}\text { WSA } \\
\text { (14 day) }\end{array}$ & $\begin{array}{l}\text { WSAP } \\
\text { (14 day) }\end{array}$ & $\begin{array}{c}\text { WCP } \\
\text { (14 day) }\end{array}$ & $\begin{array}{c}\text { HT (healing } \\
\text { time) }\end{array}$ \\
\hline \multirow{3}{*}{$\begin{array}{l}\text { A } \\
\text { Non } \\
\text { diabetic }\end{array}$} & Gp 1 (C) & $\begin{array}{c}0.3 \\
\pm 0.05^{\mathbf{b}}\end{array}$ & $\begin{array}{c}44.4 \\
\pm 7.4^{\mathrm{b}}\end{array}$ & $\begin{array}{c}55.6 \\
\pm 7.4^{\mathrm{b}}\end{array}$ & $\begin{array}{c}0.1 \\
\pm 0.04^{b}\end{array}$ & $\begin{array}{c}18.3 \\
\pm 5.1^{b}\end{array}$ & $\begin{array}{c}81.7 \\
\pm 5.1^{b}\end{array}$ & $\begin{array}{l}0.0^{\mathbf{b}} \\
0.0^{\mathbf{b}}\end{array}$ & $\begin{array}{l}0.0^{\mathbf{b}} \\
0.0^{\mathbf{b}}\end{array}$ & $100 \%^{b}$ & $\begin{array}{c}14.3 \\
\pm 0.5^{b}\end{array}$ \\
\hline & Gp 2 (A) & $\begin{array}{c}0.1 \\
\pm 0.04^{\mathbf{b}}\end{array}$ & $\begin{array}{c}18.3 \\
\pm 5.1^{b}\end{array}$ & $\begin{array}{c}81.6 \\
\pm 5.1^{b}\end{array}$ & $\begin{array}{c}0.004 \\
\pm 0.004^{\mathbf{b}}\end{array}$ & $\begin{array}{c}0.5 \\
\pm 0.5^{\mathrm{b}}\end{array}$ & $\begin{array}{c}99.4 \\
\pm 0.5^{\mathbf{a b}}\end{array}$ & $\begin{array}{l}0.0^{\mathbf{b}} \\
0.0^{\mathbf{b}}\end{array}$ & $\begin{array}{l}0.0^{\mathbf{b}} \\
0.0^{\mathbf{b}}\end{array}$ & $100 \%^{b}$ & $\begin{array}{c}7.6 \\
\pm 0.5^{\text {ab }}\end{array}$ \\
\hline & Gp 3 (P) & $\begin{array}{c}0.2 \\
\pm 0.05^{\mathbf{b}}\end{array}$ & $\begin{array}{c}28.1 \\
\pm 6.6^{b}\end{array}$ & $\begin{array}{c}71.8 \\
\pm 6.6^{b}\end{array}$ & $\begin{array}{c}0.01 \\
\pm 0.01^{b}\end{array}$ & $\begin{aligned} & 1.8 \\
\pm & 1.6^{b}\end{aligned}$ & $\begin{array}{c}98.1 \\
\pm 1.6^{\mathbf{a b}}\end{array}$ & $\begin{array}{l}0.0^{\mathbf{b}} \\
0.0^{\mathbf{b}}\end{array}$ & $\begin{array}{l}0.0^{\mathbf{b}} \\
0.0^{\mathbf{b}}\end{array}$ & $100 \%^{b}$ & $\begin{array}{c}8.3 \\
\pm 1.1^{\text {ab }}\end{array}$ \\
\hline \multirow{3}{*}{$\begin{array}{l}\text { B } \\
\text { Diabetic }\end{array}$} & Gp 4 (C) & $\begin{array}{c}0.6 \\
\pm 0.08^{\mathrm{a}}\end{array}$ & $\begin{array}{c}87.1 \\
\pm 11.1^{\mathrm{a}}\end{array}$ & $\begin{array}{r}12.8 \\
\pm 11.1^{\mathrm{a}}\end{array}$ & $\begin{array}{c}0.3 \\
\pm 0.05^{\mathrm{a}}\end{array}$ & $\begin{array}{c}44.4 \\
\pm 7.4^{\mathrm{a}}\end{array}$ & $\begin{array}{c}55.6 \\
\pm 7.4^{\text {a }}\end{array}$ & $\begin{array}{c}0.25 \\
\pm 0.05^{\mathrm{a}}\end{array}$ & $\begin{array}{r}0.32 \\
\pm 6.3^{\mathrm{a}}\end{array}$ & $\begin{array}{c}67.3 \\
\pm 6.3^{\mathrm{a}}\end{array}$ & $\begin{array}{c}23.3 \\
\pm 0.5^{\mathrm{ab}}\end{array}$ \\
\hline & Gp 5 (A) & $\begin{array}{c}0.3 \\
\pm 0.05^{\mathbf{b}}\end{array}$ & $\begin{array}{c}40.1 \\
\pm 7.4^{\mathbf{b}}\end{array}$ & $\begin{array}{c}59.9 \\
\pm 7.4^{\mathrm{b}}\end{array}$ & $\begin{array}{c}0.08 \\
\pm 0.02^{b}\end{array}$ & $\begin{array}{r}11 \\
\pm 3.6^{\mathrm{b}}\end{array}$ & $\begin{array}{c}88.9 \\
\pm 3.6^{\mathrm{b}}\end{array}$ & $0.0^{\mathbf{b}}$ & $\begin{array}{l}0.0^{\mathbf{b}} \\
0.0^{\mathbf{b}}\end{array}$ & $100 \%^{b}$ & $\begin{array}{c}13.0 \\
\pm 1.0^{\mathrm{b}}\end{array}$ \\
\hline & Gp 6 (P) & $\begin{array}{c}0.3 \\
\pm 0.05^{b}\end{array}$ & $\begin{array}{c}40.1 \\
\pm 7.5^{b}\end{array}$ & $\begin{array}{c}59.9 \\
\pm 7.4^{b}\end{array}$ & $\begin{array}{c}0.08 \\
\pm 0.02^{\mathbf{b}}\end{array}$ & $\begin{array}{c}11 \\
\pm 3.6^{\mathrm{b}}\end{array}$ & $\begin{array}{c}88.9 \\
\pm 3.6^{\mathrm{b}}\end{array}$ & $0.0^{\mathbf{b}}$ & $\begin{array}{l}0.0^{\mathbf{b}} \\
0.0^{\mathbf{b}}\end{array}$ & $100 \%^{b}$ & $\begin{array}{c}13.0 \\
\pm 1.0^{b}\end{array}$ \\
\hline
\end{tabular}

$\mathbf{a} \rightarrow$ is referring to significant changes in comparison with normal control (group 1) when $\mathrm{P}<0.05 \%$.

$\mathbf{b} \rightarrow$ is referring to significant changes in comparison with diabetic control (group 4) when $\mathrm{P}<0.05 \%$. 


\section{Results}

\section{Wound measurements}

The measurement of wound surface (WSA, WSAP and WCP) (Table 1) showed significant decrease in subgroups 1-3, 5, 6 after 3, 7 and 14 dpi in comparison with group 4. Meanwhile, group 4 displayed significant decrease in WCP when compared to nondiabetic control and the other groups.

However, the mean level of healing time declared significant decrease in non-diabetic treated subgroups $(2,3)$ when compared to the control subgroup (1), while, significantly increased in diabetic subgroup $(5,6)$ but not reach to subgroup 1 . The healing time in diabetic rats (subgroups 5,6) and non-diabetic animals (subgroups 1-3) showed significant change in comparison to diabetic rats (subgroup 4).

Quantitative ELISA analysis of TNF- $\alpha$ and IL-10 in plasma

As shown in Table (2), the mean level of plasma TNF- $\alpha$ was significantly increased in subgroups $(4,5)$ when compared to nondiabetic control (subgroup 1) and other subgroups, while subgroups (2, 3 and 6) revealed significant decrease in comparison with (subgroup 1). In addition, all subgroups (1-3, 5-6) revealed significant decrease when compared to (subgroup 4). Otherwise, interleukin 10 of the subgroups $(2,3,5$ and 6) showed significant increases when compared to subgroups $(1,4)$ which noticed significant reduction when compared with subgroup 1 .

\section{Pathological results}

Clinical signs

The clinical signs in all non-diabetic subgroups after the creative skin wound along 14 dpi showed rapid healing process without complication and mortalities. Moreover, accelerated healing was manifested by obvious narrowing and contraction in the wound in the treated groups (propolis and Aloe vera) than the control, mainly at 3, 7 dpi with complete closure in all groups at 14 dpi (Figure 1 A). Meanwhile, the majority of diabetic subgroups displayed general signs such as inactivity, rapid respiration and paleness of the eye. In addition, cannibalism mainly in untreated diabetic subgroup 4 exhibited delay in healing process with scar formation when compared to other diabetic and non-diabetic subgroups. Wounds in some rats of subgroups 4 showed complication (septic wound) and wider with scar formation on the surface. Meanwhile, the treated subgroups with (propolis and Aloe vera) particularly at $3,7 \mathrm{dpi}$, showed progression in healing process without any complication and fully healed after $14 \mathrm{dpi}$ (Figure $1 \mathrm{~B}$ ).

Table 2: Mean \pm Standard Deviation of the tumor necrosis factor (TNF- $\alpha$ ), and interleukin 10 (IL 10) of among different groups at time of wound healing.

\begin{tabular}{lccc}
\hline \multirow{2}{*}{ Groups } & Subgroups & \multicolumn{2}{c}{ Mean \pm Standard Deviation } \\
\cline { 3 - 4 } & & TNF- $\alpha$ & IL 10 \\
\hline A & $\mathbf{1}(\mathbf{C})$ & $75.3 \pm 4.5^{\mathbf{b}}$ & $110 \pm 5.5^{\mathbf{b}}$ \\
Non Diabetic & $\mathbf{2}(\mathbf{A})$ & $40.6 \pm 5.1^{\text {ab }}$ & $331.6 \pm 12.5^{\text {ab }}$ \\
& $\mathbf{3}(\mathbf{P})$ & $39 \pm 3^{\text {ab }}$ & $265.6 \pm 6^{\text {ab }}$ \\
B & $\mathbf{4}(\mathbf{C})$ & $286.3 \pm 6.5^{\text {a }}$ & $90.6 \pm 3^{\text {a }}$ \\
Diabetic & $\mathbf{5 ( A )}$ & $90.6 \pm 6^{\text {ab }}$ & $295 \pm 5^{\text {ab }}$ \\
& $\mathbf{6}(\mathbf{P})$ & $54.3 \pm 4.5^{\text {ab }}$ & $169.3 \pm 4^{\text {ab }}$ \\
\hline
\end{tabular}

$\mathbf{a} \rightarrow$ is referring to significant changes in comparison with normal control group (group 1) when $\mathrm{P}<0.05 \%$.

$\mathbf{b} \rightarrow$ is referring to significant changes in comparison with diabetic control group (group 4 ) when $\mathrm{P}<0.05 \%$. 


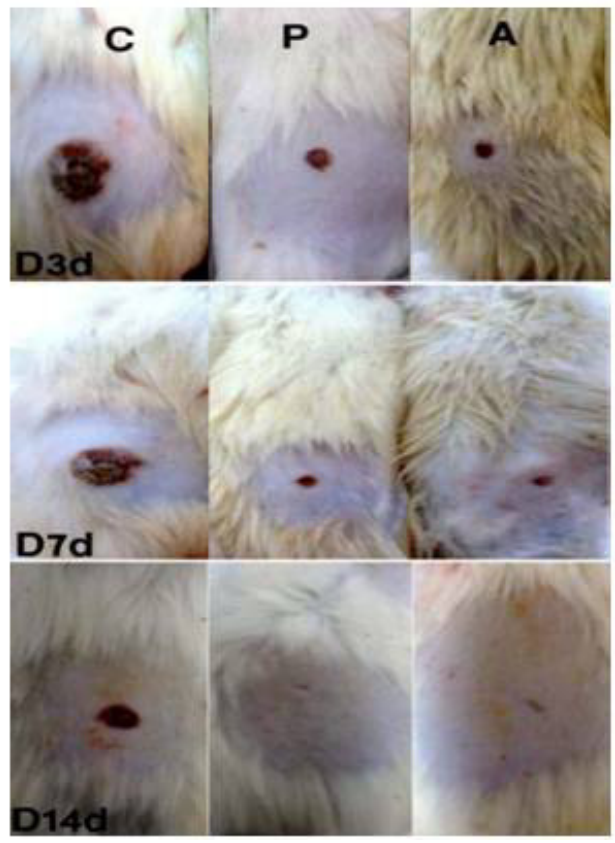

(A)

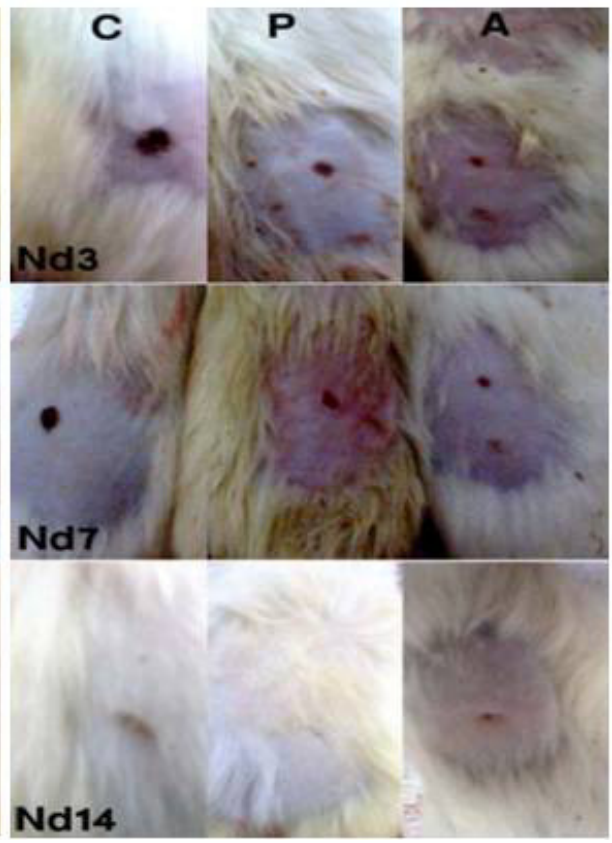

(B)

Figure 1: Wound contraction in non-diabetic groups (A) showing obvious narrowing in the artificial wound in the treated groups with (proplis and A.vera) than the control particularly at 3,7 dpi with complete closure in all groups at 14dpi. (B) Wound contraction in diabetic groups showing septic wound more wider with scar formation in the artificial wound in the control than the treated groups with (proplis and A. vera) particularly at 3, $7 \mathrm{dpi}$, but at 14dpi complete closure in the treated groups with (proplis and A.vera) compared with control group, which still opened with scar formation. C: Control, P: Proplis, A: A. vera.

\section{Histopathological findings}

The non-diabetic rats in subgroup 1 (3 dpi) showed wound gap with the presence of necrotic debris and few inflamed cells. The gap was found with wide excess necrotic debris, neutrophils and pus on $7 \mathrm{dpi}$, while, complete absence of the gap and reepithelization occurred at $14 \mathrm{dpi}$. Moreover, subgroups $(2,3)$ displayed narrow gap containing few debris over granulation tissue, besides few inflammatory cells on 3 dpi. Meanwhile, fully aseptic granulation tissue partially covered with epithelium was common at $7 \mathrm{dpi}$ particularly in subgroup 2. Complete reepithelization over fully regenerated dermis containing skin adnexa were seen $14 \mathrm{dpi}$
(Figure 2). The diabetic rats in subgroup (4) 3 dpi showed intense necrotic debris and pus with less granulation tissue and absence of epidermal appendages in wounds at 3, $7 \mathrm{dpi}$. After 14 dpi, presence of collagen bundle, less and few adnexa in dermis and partial reepithelization were observed. However, treated subgroups (4 and 6) showed narrow inflammatory areas with inflammatory cells over granulation tissue at 3, 7 dpi. Excess fibroblasts, angiogenesis and few neutrophils were common also at $7 \mathrm{dpi}$. Epidermal layers (reepithelization) over mature collagen layers containing excess skin adnexa were common at 14 dpi (Figure 3). 


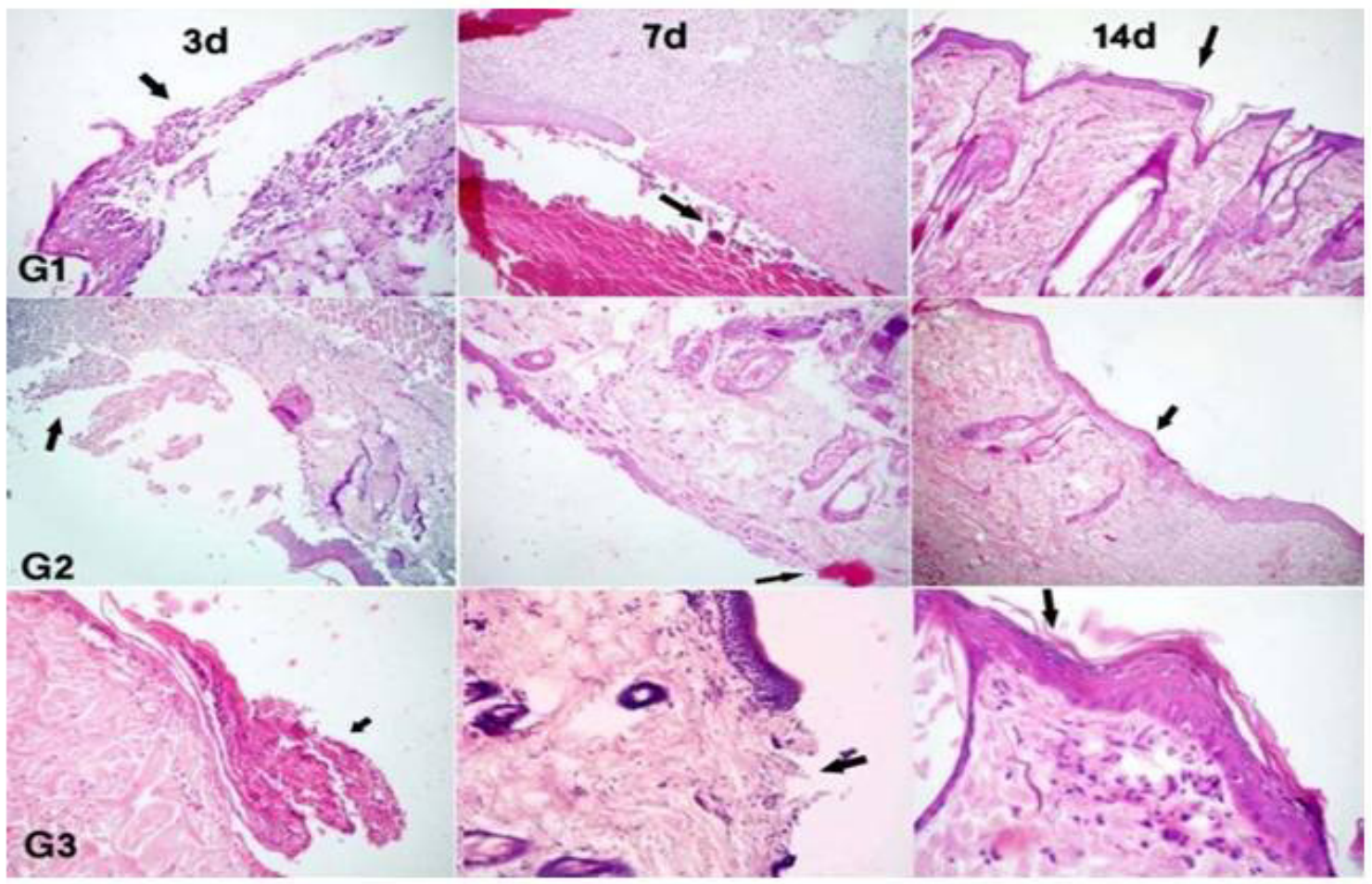

Figure 2: photomicrograph sections of artificial skin wound of non-diabetic subgroups (1-3): Subgroup 1 (G1) 3dpi showing wound gap with presence of necrotic debris and a few inflamed cells. The gap still wide excess necrotic debris, neutrophils and pus on $7 \mathrm{dpi}$ while complete absence of the gap and reepithelization were occurred at 14 dpi. Subgroups 2 and 3 (G2, G3) showing narrow gap containing few debris over granulation tissue, besides few of inflammatory cells on 3 dpi. Meanwhile, fully aseptic granulation tissue partially covered with epithelium were commen at $7 \mathrm{dpi}$ particulary in subgroup 2 (G2). Complete reepithelization over fully regenerated dermis and skin were seen $14 \mathrm{dpi}$. (H, E, x 100- 300). 


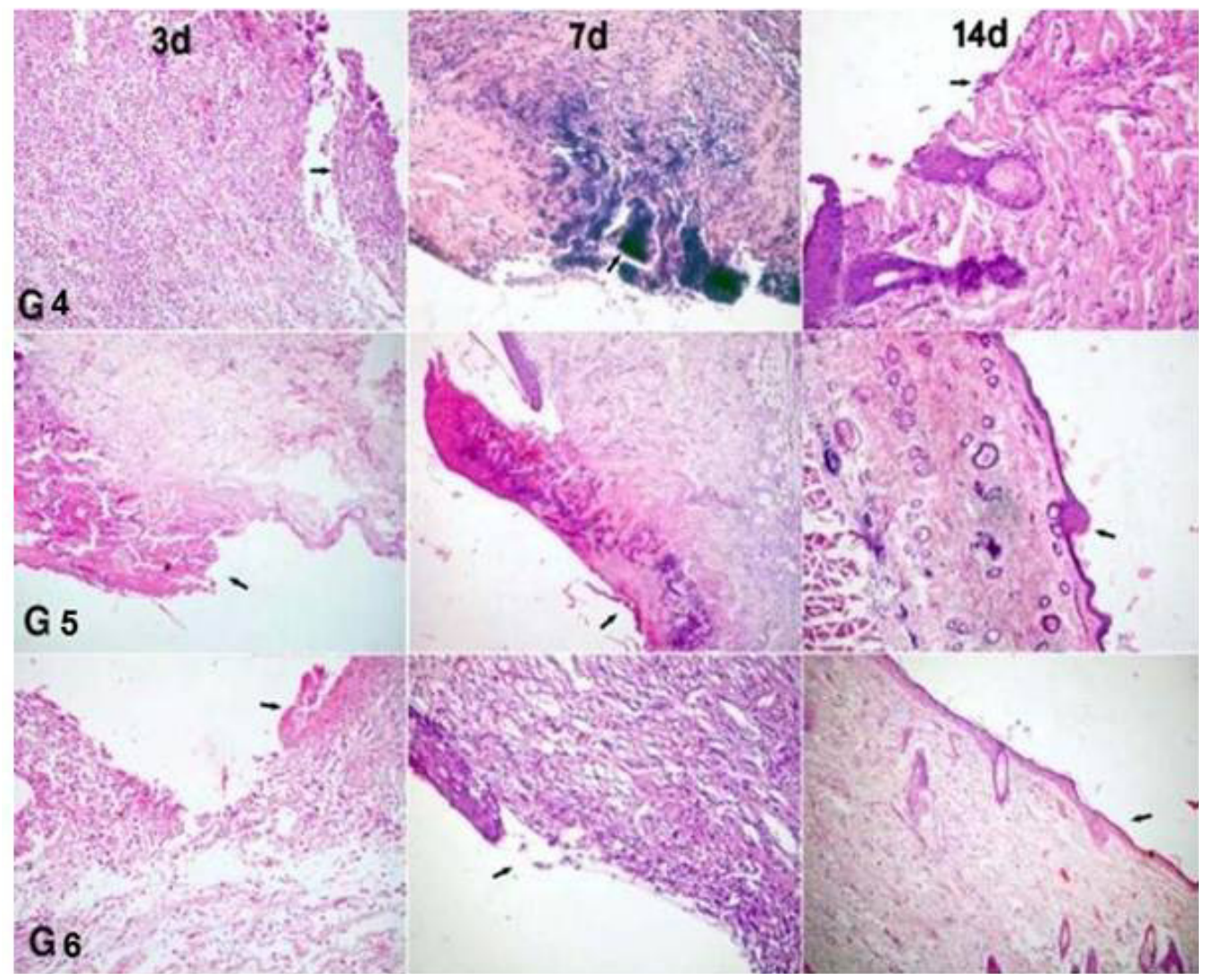

Figure 3: photomicrograph sections of artificial skin wound of diabetic subgroups (4-6): Subgroup 4 (G4) 3dpi showing intense necrotic debris and pus with less granulation tissue and absence of epidermal appendages in wounds at 3, 7dpi. but after $14 \mathrm{dpi}$, presence of collagen bundle, less and few adnexa in dermis and partial reepithelization. However, treated subgroups (4 and 6) showing narrow inflammatory areas with inflammatory cells over granulation tissue at 3, 7dpi. Excess fibroblasts, angiogenesis and few neutrophils were common also at $7 \mathrm{dpi}$. epidermal layers (reepithelization) over mature collagen layers containing excess skin adnexa were common at $14 \mathrm{dpi}$.

\section{Discussion}

In the present study, the mean level of wound surface (WSA, WSAP and WCP) showed significant decrease in all subgroups $(1-3,5,6)$ after 3,7 and 14 dpi in comparison with subgroup 4 which displayed significant decrease in WCP when compared to nondiabetic control and the other subgroups. In addition to, the level of TNF- $\alpha$ significantly decreased in non-diabetic subgroups $(2,3)$ when compared to non-diabetic control subgroup (1) and significantly increased in diabetic subgroups $(4,5)$ when compared to subgroup (1). On contrary, the mean level of interleuken-10 was significantly decreased in diabetic groups (4) in comparison to nondiabetic group (2).
Pro-inflammatory cytokines such as TNF- $\alpha$ was elevated shortly after induction of wound in humans and animal wound models [7]. It is synthesized by macrophages and other cells such as lymphocytes, polymorphonuclear leukocytes, eosinophils, astrocytes, Langerhans cells and Kupffer cells. Diabetic wound healing impaired fibroblast proliferation due to increased levels of TNF- $\alpha$ $[21,22]$. Hyperglycemia-induced oxidative stress, which promotes inflammation where increase endothelial cell damage, permeability of microvascular and release of proinflammatory cytokines including TNF- $\alpha$ $[6,23]$. Diabetes is known to compromise macrophage function including phagocytosis activity [24]. The increased level of IL-10 inhibits the Th1 immune response, causes 
expression of anti-inflammatory molecules as protease inhibitors and TNF- $\alpha$ antagonist and suppresses the functions of macrophages and neutrophils hence causing decreased TNF- $\alpha$ level $[25,26]$.

IL-10 is produced by many different cell types, including $\mathrm{B}$ and $\mathrm{T}$ lymphocytes and macrophages, and affects both those cells and others, such as neutrophils [27]. In diabetic models, increased levels of the proinflammatory cytokines such as TNF- $\alpha$ and IL-6 and decreased levels of antiinflammatory IL-10 compared to non-diabetic healing wound were reported [28, 29]. The previous results of the wound characters could interpret the histopathological conditions of non-diabetic control rats in subgroup (1) which was not treated 3 days post-injury showed few inflammatory cells in the wound bed with necrotic cells debris followed by severe destruction of the blood capillaries, excess necrotic debris, neutrophils and pus $7 \mathrm{dpi}$. The wound at 14 days showed completion of reepithelization, with few scar formation. While, the diabetic control subgroup (4) revealed pus formation filled the wound gap with fibrin clot and severe inflammation in neighbored areas around the wound bed at 3 days, but at $7 \mathrm{dpi}$ partial reepithelization over granulation tissue which contain little inflammatory cells were noticed.

The wound at 14 days post-injury showed epidermal layers over mature collagen bundles containing skin adnexa (hair follicles, sweat glands). This is correlated to a significant elevation in cytokines as TNF- $\alpha$ with reduction in IL-10. TNF- $\alpha$ is a proinflammatory cytokine, responsible for the acute stage inflammatory reaction increasing adhesion molecules expression, facilitate the immigration of inflammatory cells and activate pro-fibrotic mechanisms in the sub-epithelium [30].

TNF- $\alpha$ and IL- $1 b$ are the most powerful pathological cytokines, causing cell degeneration, apoptosis and necrosis. Topical application of Aloe vera in the skin wound creates aseptic condition of the wound and accelerated the healing process in the wound bed, together with fibroblast proliferation, in addition to aggregations of some round cells and completes epithelization. Previous studies supported our result, for wound-healing, antibiotic, and anticarcinogenic properties of the active compounds present in the leaves of Aloe vera [31]. Moreover, topical application of Aloe vera stimulated fibroblast activity and collagen proliferation, in addition to increasing the content of granulation tissue and its maturation and remodeling via tissue cross linking by increasing the aldehyde content and decreasing the acid solubility, in addition, Aloe vera also increased levels of hyaluronic acid and dermatan sulphate as extracellular matrix in granulation tissue [32]. An increase in the blood supply was observed after Aloe vera gel treatment and it has been suggested that increased oxygen access is one of the factors enhanced by Aloe vera due to the presence of angiogenic component [33]. In this study, animals treated with propolis revealed primarily somewhat inflamed areas, with aggregation of few leukocytic cells with fibroblast proliferation. While, the treatment wound with propolis for $14 \mathrm{dpi}$ exhibited complete re-epithelization.

Topical application of propolis on surgical wounds affected the number of mast cells (master inflammatory cells) recruited in these sites, and suggested two well-known antiinflammatory components which present in propolis, namely caffeic acid and artepillin C. Moreover, active molecules inflammation produced by mast cells can be inhibited by several flavonoids present in propolis. In our study, propolis was found to decrease the level of pro-inflammatory cytokines secretion such as TNF- $\alpha$ [34]. Another study revealed that chrysin present in propolis decreased gene expression of pro-inflammatory cytokines, such as TNF- $\alpha$, IL-1b, IL-4 and IL-6 [35].

\section{Conclusion}

It could be concluded that propolis $10 \%$ and aloe vera accelerated wound healing in both non-diabetic and diabetic rats without complications.

\section{Conflict of interest}

All the authors have no conflict of interest to declare. 


\section{Acknowledgements}

The authors thank Zeinab A. Sayed, Ph D of Clinical Pathology, Veterinary administration, Qena, Egypt for great assistance in statistics analysis.

\section{References}

[1] Ahmed, M. F.; Kazim, S. M.; Ghori, S. S.; Mehjabeen, S. S.; Ahmed, S. R.; Ali, Sh. M. and Ibrahim, M. (2010): Antidiabetic activity of Vinca rosea extracts in Alloxaninduced Diabetic rats. Int $\mathrm{J}$ Endocrinol,2010:841090.

[2] Mir, M. S.; Darzi, M. M.; Khan, H. M.; Kamil, S. A.; Sofi, A. H. and Wani, S. A. (2013): Pathomorphological effects of Alloxan induced acute hypoglycaemia in rabbits. Alexandria Journal of Medicine, 49(4): 343-353.

[3] Bastaki, S. (2005): Series 646. Geneva: World Health Organization 1980. 21. World Health Organization Study Group. Diabetes Mellitus: WHO Technical Report, Series 727.

[4] Sy, G. Y., Cisse, A., Nongonierma, R. B., Saw, M., Mbodj, N. A., and Faye, B. J. (2005): Pharmacognostical studies and phytochmecial screening for active compounds in barleria Montana nees using various solvents. J. Ethnopharmacol., 98: 171-175.

[5] Galkowska, H.; Olszewski, W. L.; Wojewodzka, U.; Rosinski, G. and Karnafel, W. (2006): Neurogenic factors in the impaired healing of diabetic foot ulcers. JSurg Res, 134(2): 252-258.

[6] Wen, Y.; Gu, J.; Li, S. L.; Reddy, M. A.; Natarajan, R. and Nadler, J. L. (2006): Elevated glucose and diabetes promote interleukin-12 cytokine gene expression in mouse macrophages. Endocrinol,147(5):2518-2525.

[7] Barrientos, S.; Stojadinovic, O.; Golinko, M. S.; Brem, H. and Tomic-Canic, M. (2008): Growth factors and cytokines in wound healing, "Wound Repair and Regeneration, 16(5):585-601.

[8] Lucas, T.; Waisman, A.; Ranjan, R.; Roes, J.; Krieg, T.; Müller, W.; Roers, A. and
Eming, S.A. (2010): Differential roles of macrophages in diverse phases of skin repair. J Immunol,184(7): 3964-3977.

[9] Wu, J. (2008): Anti-inflammatory ingredients. J Drugs Dermatol, 7 (Suppl 7): 13-16.

[10] Casey, SH. J. and Mackenzie Goldthwait, D.V. M. (2009): Considering Aloe Vera with Wildlife. Article, ewildagain.org: 12.

[11] Oridupa, O.A.; Saba, A.B. and Sulaiman, L.K. (2011): Preliminary report on the antiviral activity of the ethanolic fruit extract of Lagenaria breviflora Roberts on Newcastle Disease virus. TropVet, 29(1):22-33.

[12] Ramos A. F. N. and Miranda J. D. (2007): Propolis: A review of its antiinflammatory and healing actions. J Venom Anim Toxins incl Trop Dis, 13(4): 697-710.

[13] Ali, Z. H. and Dahmoush, H. M. (2012): Propolis versus Daktarin in mucosal wound healing. Life Science Journal Acta Zhengzhou University Overseas Edition, 9 (2): 624-636.

[14] Foster, S. (2009): National center for complementary and alternative medicine. National Institute of Health. WW://nccam.nih.gov/health/aloevera/La ngmead, L, M. Feakins, S.

[15] Temesio, P., Ross, N., and Alvarez, R. (2011): Topical treatment with propolis dressings of poor healing wound ulcers in diabetic patients. JAAS2012, 19: 788795.

[16] Carvalho, P.T.C.; Mazzer, N.; Reis, F.A.; Belchior, A. C. G. and Silva, I. S. (2006): Analysis of the influence of low-power $\mathrm{HeNe}$ laser on the healing of skin wounds in diabetic and non-diabetic rats. Acta Cir Bras, 21(3):177-183.

[17] Underwood, W.; Anthony, R.; GwaltneyBrant, S.; Poison, A. S. and Meyer, R. (2013): AVMA Guidelines for the Euthanasia of Animals:2013 Edition. Schaumburg, IL: American Veterinary Medical Association. 
www.avma.org/KB/Policies/Documents/ euthanasia.pdf

[18] Sun, H.; Zhang, J.; Chen, F.; Chen, X.; Zhou, Z. and Wang, $\mathrm{H}$. (2015):Activation of RAW264.7 macrophages by the polysaccharide from the roots of Actinidia eriantha and its molecular mechanisms. Carbohydr polym, 121: 388-402.

[19] Culling, C. F. A., Allison, R. T., and Barr, W. T. (1985): Cellular Pathology Technique. Butterworth \& Co. (Publ.). Ltd., London.

[20] Borenstein M., Rothstein H., and Cohen J. (1997): Sample power statistics. 1.0. SPSS, Inc., Chicago.

[21] Tracey, K. J. and Cerami, D. A. (1994): Tumour necrosis factor: a pleiotropic cytokine and therapeutic target. Annu Rev Med, 45(1): 491-503.

[22] Siqueira, M. F.; Li, J.; Chehab, L.; Desta, T.; Chino, T.; Krothpali, N.; Behl, Y.; Alikhani, M.; Yang, J.; Braasch, C. and Graves, D.T. (2010): Impaired wound healing in mouse models of diabetes is mediated by TNF- $\alpha$ dysregulation and associated with enhanced activation of forkhead box $\mathrm{O} 1$ (FOXO1). Diabetologia, 53(2): 378-388.

[23] Xu, F.; Zhang, C. and Graves, D. T. (2013): Abnormal Cell Responses and Role of TNF- $\alpha$ in Impaired Diabetic wound Healing. Biomed Res Int. 2013:754802. doi: 10.1155/2013/754802

[24] Su, D., Coudriet, G. M.;Hyun Kim, D.; Lu, Y.; Perdomo, G.; Qu, S.; Slusher, S.; Tse,H.M.; Piganelli, J.; Giannoukakis, N.; Zhang, J. and Dong, H.H. (2009): FoxO1 links insulin Resistance to Proinflammatory Cytokine IL-1 $\beta$ Production in Macrophages Diabetes, 58(11): 26242633.

[25] Maruyama, K.; Asai, J.; Ii, M.; Thorne, T.; Losordo, D.W. and D'Amore, P.A. (2007): Decreased macrophage number and activation lead to reduced lymphatic vessel formation and contribute to impaired diabetic wound healing. Am J Pathol,170(4): 1178-1191.

[26] Mocellin, S.; Marincola, F., M.; and Young, H. A. (2005): Interleukin-10 and the immune response against cancer: a counterpoint. J Leukoc Biol, 78(5): 1043-51.

[27] Salgado, A. J.; Reis, R. L.; Sousa, N. J. and Gimble, J. M. (2010): Adipose tissue derived stem cells secretome: soluble factors and their roles in regenerative medicine. Curr Stem Cell Res Ther, 5(2): 103-10.

[28] Waal, de. Malefyt, R., Yssel, H., Roncarolo, M. G., Spits, H., and de Vries, J. E. (1992): Interleukin-10. Curr Opin Immunol, 4: 314-320.

[29] Khanna, S.; Biswas, S.; Shang, Y.; Collard, E.; Azad, A.; Kauh, C.; Bhasker, V.; Gordillo, G.M.; Sen, C.K. and Roy, S. (2010): Macrophage dysfunction impairs resolution of inflammation in the wounds of diabetic mice. PLoS One, 5(3):e9539.

[30] Wetzler, C.; Kampfer, H.; Stallmeyer, B.; Pfeilschifer, J. and Frank, S. (2000): Large and sustained induction of chemokines during impaired wound healing in the genetically diabetic mouse: prolonged persistence of neutrophils and macrophages during the late phase of repair. J Invest Dermatol, 115(2):245253.

[31] Imamura, S.; Matsukawa, A.; Ohkawara, S.; Kagayama, M.; and Yoshinaga, M. (1997): Involvement of tumor necrosis factor-a, interleukin-I $\mathrm{p}$, interleukin-8, and interleukin-I receptor antagonist in acute lung injury caused by local Schwartzman reaction. Pathol Int, 47(1): 16-24.

[32] Chen, S. H.; Lin, K. Y.; Chang, C. C.; Fang, C. L.; and Lin, C. P. (2007): Aloeemodin-induced apoptosis in human gastric carcinoma cells. Food Chem Toxicol, 45(11): 2296-2303.

[33] Chithra, P., Sajithlal, G. B., and Chandrakasan, G. (1998): Influence of Aloe vera on collagen characteristics in 
healing dermal wounds in rats. Mol Cell Biochem, 181(1-2): 71-76.

[34] Lee, M. J.; Yoon, S. H.; Lee, S. K.; Chung, M. H.; Park, Y. I.; Sung, C. K. et al. (1995): In vivo angiogenic activity of dichloromethane extracts of Aloe vera gel. Arch Pharm Res, 18(5): 332-335.
[35] Girgin, G.; Baydar, T.; Ledochowski, M.; Schennach, H.; Bolukbasi, D.N.; Sorkun, K.; Salih, B.; Sahin, G.; Fuchs, D. et al. (2009): Immunomodulatory effects of Turkish propolis: changes in neopterin release and tryptophan degradation. Immunobiology, 214(2): 129-134.

$$
\begin{aligned}
& \text { الملخص العربي }
\end{aligned}
$$

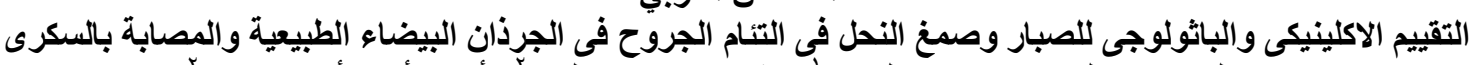

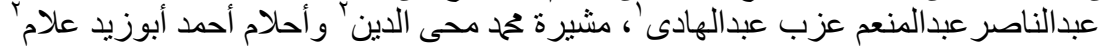

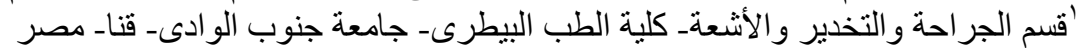

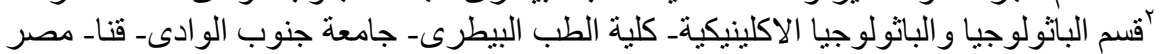

أجريت هذه الدر اسة لتتقييم مدى كفاءة بعض المواد البيولوجية الحيوية فى سر عة التئام الجروح فى كل من الحيو انات السليمة

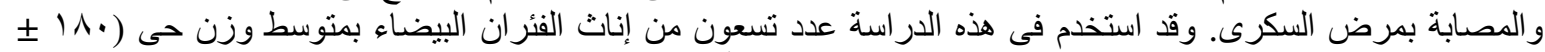

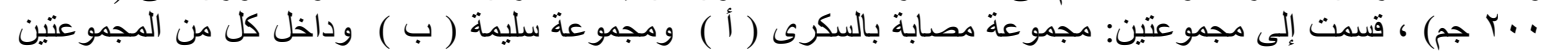

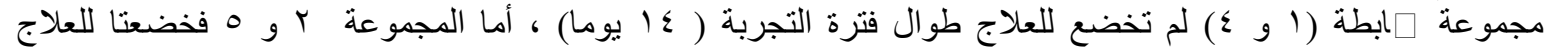

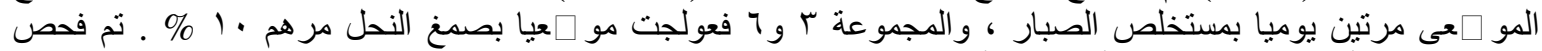

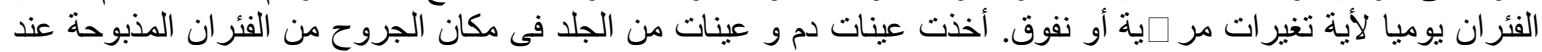

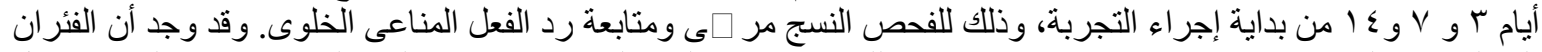

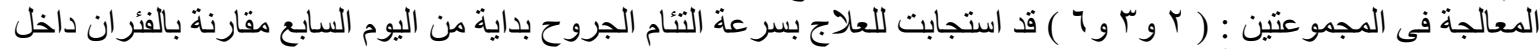

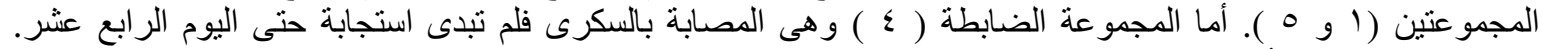

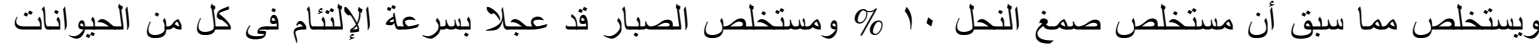
السليمة والمصابة بالسكرى. 